\title{
Ecological benefits of Anystis baccarum in an orchard ecosystem and the need for its conservation
}

\author{
${ }^{1 *}$ A. G. S. Cuthbertson; ${ }^{2}$ A. K. Murchie \\ ${ }^{1}$ The Food and Environment Research Agency, Sand Hutton, York YO41 1LZ, UK \\ ${ }^{2}$ The Agri-Food and Biosciences Institute, Newforge Lane, Belfast BT9 5PX, UK \\ Received 17 December 2009; $\quad$ revised 1 February 2010; accepted 18 April 2010; available online 1 September 2010
}

\begin{abstract}
Integrated pest management programs are very important in the control of invertebrate pests within apple orchards. Many current integrated pest management strategies concentrate on specialist predatory species. However, generalist beneficial insects, such as several mite species, must also be fully researched for their potential in controlling pests. Previous research has shown that the generalist predatory mite Anystis baccarum (Linnaeus) can offer much potential in controlling invertebrate pests within Northern Irish apple orchards. However, apple growers have been mis-identifying this beneficial species as the economic pest European fruit tree red spider mite, Panonychus ulmi (Koch). As a result, unnecessary pesticide applications have been applied against what has now been confirmed as a beneficial species. To aid apple growers in the identification of A. baccarum, identification cards were produced. Positive uptake of the cards by many apple growers has resulted in correct identification of A. baccarum from P. ulmi, and therefore, a reduction in chemical pesticide applications. The benefits of A. baccarum within orchard ecosystems is discussed.
\end{abstract}

Keywords: Beneficial mite; Biocontrol; Identification card; Pesticide

\section{INTRODUCTION}

The development of orchard integrated pest management (IPM) systems have become an increasingly important concept throughout the world. Increasing public concern over the use of chemical insecticides and their impact on the environment (Horowitz et al., 2003; Banaee et al., 2008) and nontarget species (Michaud, 2002; Goulet, 2003; Cuthbertson and Murchie, 2005a; Joy et al., 2005; Cuthbertson and Brown, 2009) is continuing to drive the need to develop new and novel means of pest control in what is an increasingly competitive business. Internationally and more specifically in the United Kingdom(UK), much research regarding orchard IPM has concentrated on the predatory mites Typhlodromous pyri Scheuten and Zetzellia mali (Ewing). These mites have been shown to have much potential to offer control of many economic invertebrate pest species (Santos, 1976 a,b;

\footnotetext{
\4 *Corresponding Author Email: andrew.cuthbertson@fera.gsi.gov.uk
} Tel.: +4401904 462 201; Fax: +4401904 462111
Easterbrook et al., 1985; Dicke et al., 1989; Croft et al., 1995). Studies have also shown T. pyri to have the potential to be successfully incorporated along with insecticide treatments for the control of orchard pests (Cranham and Solomon, 1981; Easterbrook, 1984; Cross and Berrie, 1994). However, for the full implementation and success of pest control programs within orchard ecosystems, there is also the need to investigate the potential of other generalist predatory species and determine their potential for inclusion within such schemes (Cuthbertson and Murchie, 2007a). Apple orchards form a major part of the horticultural industry within the UK, covering approximately 27,000 ha (Cuthbertson and Brown, 2006; Cuthbertson and Murchie, 2006a; Defra, 2007). Within Northern Ireland specifically, mostly culinary apples are grown, with approximately $90 \%$ of the apple production within a six-mile radius of the village of Loughgall in County Armagh. The local apple industry is highly important to the rural economy of Northern Ireland. Commercial 
apple growing (orchards 0.5 ha and above) is estimated to provide employment for upwards of 800 people on approximately 782 farms. A further 700 people can be employed on a part-time basis including $150-200$ (depending on crop size) in on-farm peeling for servicing processors (Cook, 1998). On average, Northern Ireland contributes between $20-25 \%$ of the UK's production of culinary apples (Anonymous, 1972; 1992), which overall can account for as much as $66 \%$ of total UK apple production (Carter and Shaw, 1993; Defra, 2001).

\section{Predatory fauna}

Within the Bramley's Seedling apple orchards in Northern Ireland both T. pyri and Z. mali occur, though in smaller numbers compared to their English counterparts (Cuthbertson and Murchie, 2005b). The study undertaken by Cuthbertson and Murchie (2005b) discovered that the generalist predatory mite Anystis baccarum (Linnaeus) (Fig. 1) was the most commonly occurring beneficial species within the Bramley orchards. However, upon consultation with many Northern Irish apple growers it was determined that the presence of $A$. baccarum within the orchards was unknown and that many had actively sprayed chemical insecticides against this beneficial species, confusing it with the pest Panonychus ulmi (Koch) (Fig. 2) (Cuthbertson, 2004; Cuthbertson and Murchie, 2005a; Cuthbertson and Murchie, 2007b).

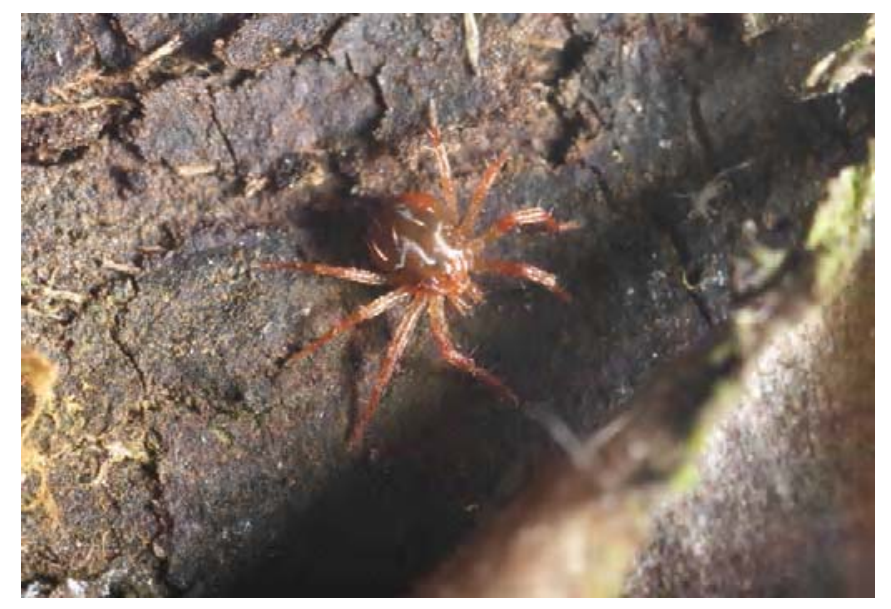

Fig. 1: The beneficial 'whirligig' mite, Anystis baccarum

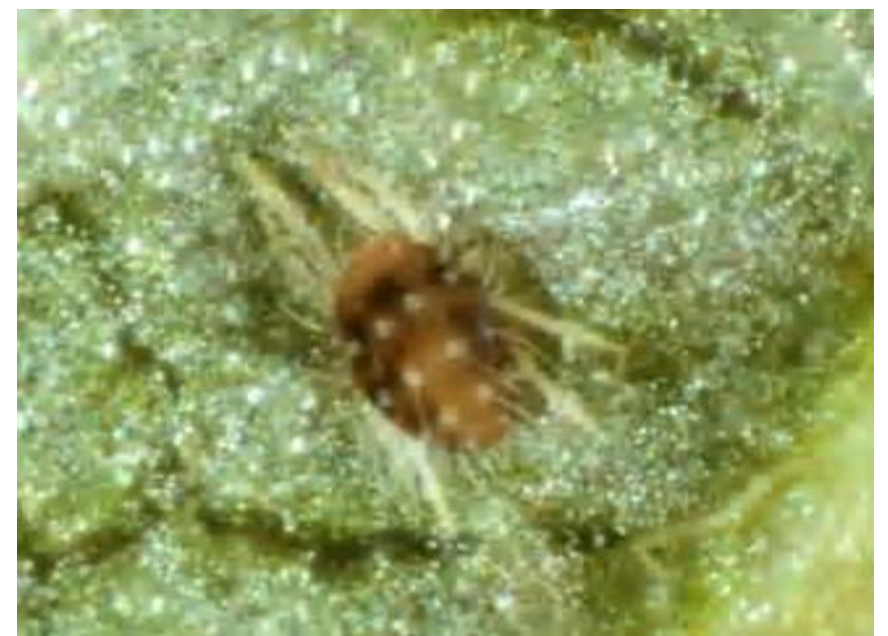

Fig. 2: European fruit tree red spider mite, Panonychus ulmi 

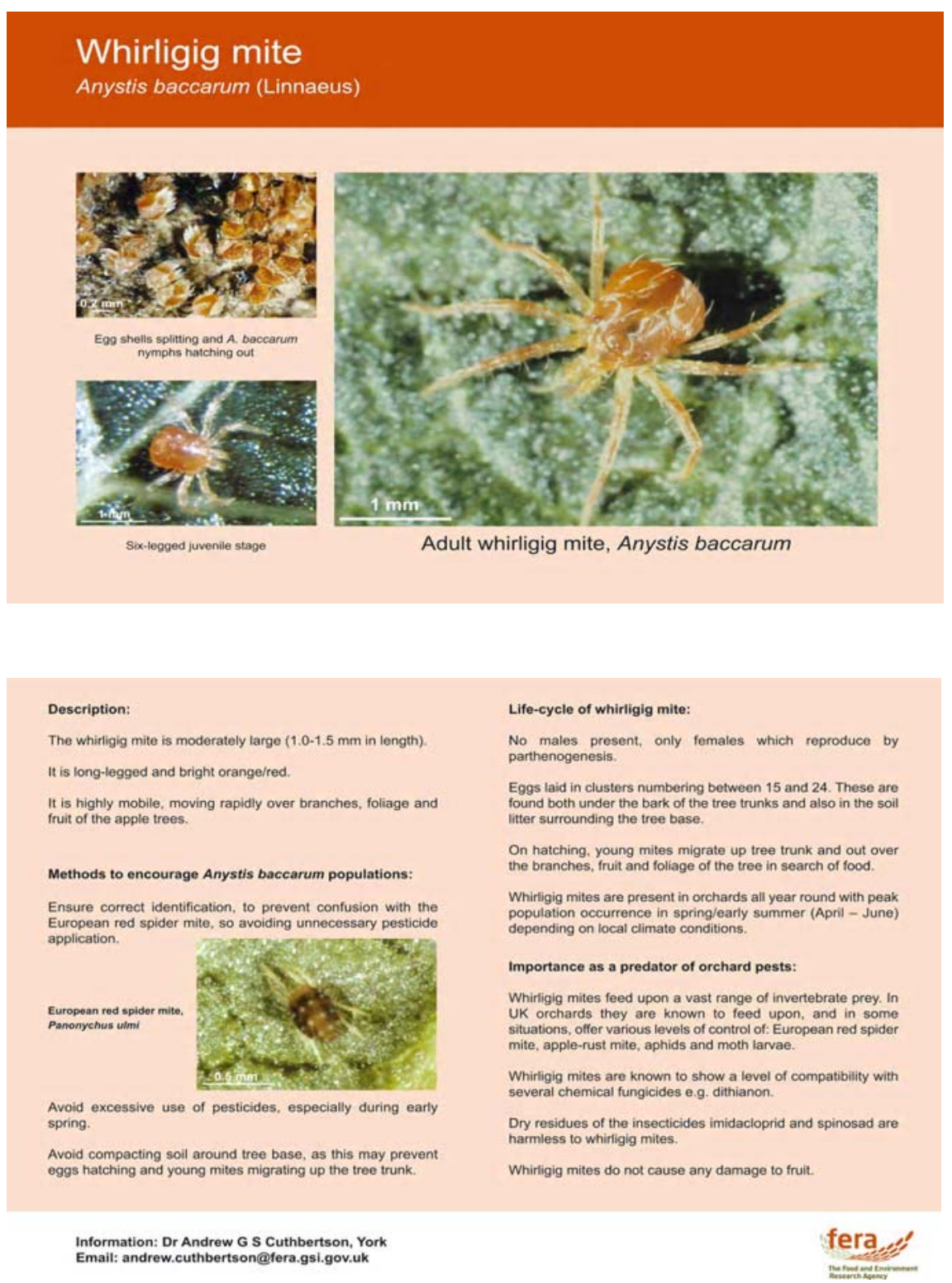

Fig. 3: The Anystis baccarum identification card

\section{Identification cards}

To help overcome the problem of mis-identification of this beneficial mite and to ensure the elimination of unnecessary pesticide sprays, A. baccarum identification cards (Fig. 3) were designed and distributed around the apple growers during the 2009 growing season. These have been gratefully received and the information uptake by the local apple growers has been very positive. As a result, several apple growers have now prevented the need to apply chemical sprays on what has been confirmed as a beneficial species within their orchards.

\section{Description of Anystis baccarum}

According to Oudemans (1937), Hooke in 1665 was the first person to find this species (Anystis baccarum) but he only referred to it as an insect mite. Linnaeus (1758) first named this species Acarus baccarum. It was renamed to Actineda baccarum by Stoll (1886) and was first called Anystis baccarum by Trägardh 


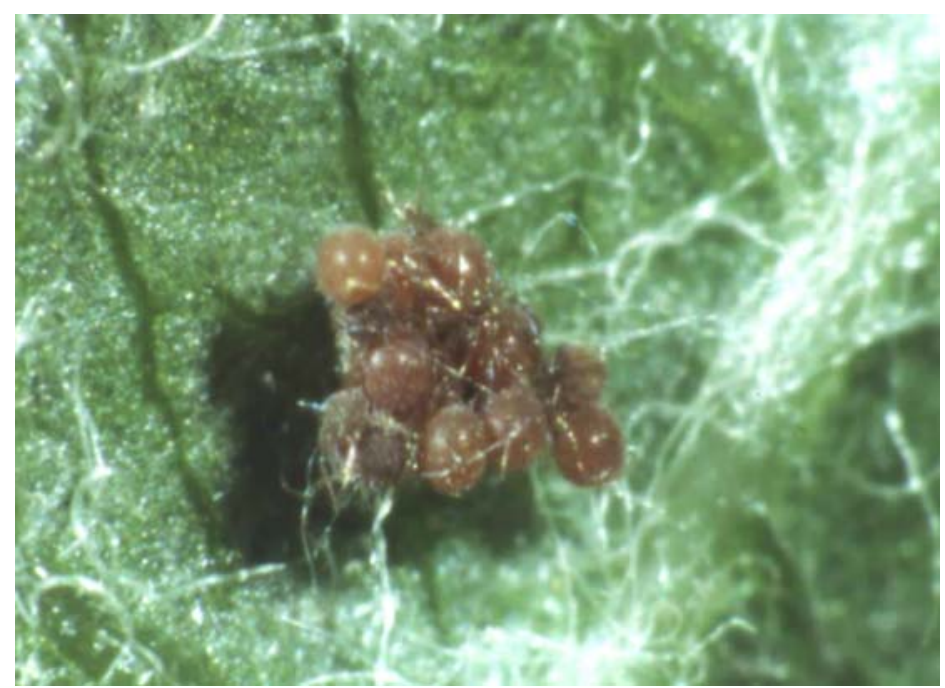

Fig. 4: Egg batch of Anystis baccarum (on leaf surface for photo)

(1905) as cited in Meyer and Ueckermann (1987). This mite belongs to the order Prostigmata which contains both predators and plant feeding species and the subfamily Anystinae (Krantz, 1978). Mites of this genus are moderately large (1.0-1.5 mm in length), long-legged and bright orange/red (Krantz, 1978; Titov, 1987). They lay eggs in batches of 15-24 (Fig. 4) in loose soil surrounding the tree base or under the tree bark. Eggs then hatch and six-legged juveniles emerge which then develop into the eight-legged adult. Certain characteristics are listed by Meyer and Ueckermann (1987) and Cuthbertson and Murchie (2007b) from which A. baccarum may be easily identified in the field. Also, the production and distribution of the identification card will aid growers in field identification of this beneficial species.

\section{Distribution of Anystis baccarum}

Anystis baccarum is a cosmopolitan species capable of surviving a range of climatic conditions and occurs in numerous places including Australia, U.S.A, Europe, Juan Fernandez Islands (close to the coast of Chile), St. Helena, Faeroe Islands, Mexico, Japan and northern and southern Africa (Meyer and Ueckermann, 1987). In Northern Ireland, mites belonging to the genus Anystis have been reported to occur (MacQuillan, 1966) but until recently no individual species had ever been identified (Cuthbertson, 2004; Cuthbertson and Murchie, 2004a; Cuthbertson, 2005). At least three other species of the genus are known to occur in the British
Isles: Anystis salicinus (Linnaeus), Anystis cornigerum (Hermann) and Anystis cursorium (Gervais). Anystis agilis Banks has also been recorded in the British Isles (Anne Baker, British Natural History Museum, London, UK, personal communication). Monitoring of $A$. baccarum populations within Northern Ireland's apple orchards proved that the mite occurred almost all year round, with peak occurrence in spring and early summer (Cuthbertson and Murchie, 2004b). This is at the same time as when pests such as red spider mite eggs are beginning to hatch and apple rust mite (Aculus schlechtendali, (Nalepa)) are beginning to migrate from their over-wintering sites out onto foliage to feed. Any prey items encountered by $A$. baccarum will be readily devoured (Baker, 1967; Cuthbertson and Murchie, 2004b). Over-wintering eggs of apple-grass aphid (Rhopalosiphum insertum, (Walker)) and red spider mite along with apple rust mite possibly act as a valuable food source to sustain populations of $A$. baccarum over the winter period when other prey items are few (Cuthbertson et al., 2003a; Cuthbertson and Murchie, 2006 b,c; Cuthbertson and Murchie, 2007 a,c).

\section{Potential biocontrol agent}

Mites of the genus Anystis have been suggested as agents for bio-control of various pest arthropods (Gerson and Smiley, 1990) as they have been observed feeding on a variety of prey species (Baker, 1967). In England, A. baccarum can become 
abundant during times of aphid infestation in cereal fields (El Banhawy et al., 1993), whereas in New Zealand, A. baccarum plays an important role in the predation of tortricid larvae in apple orchards (Baker, 1983; Cuthbertson and Murchie, 2005c). Anystis baccarum was also found to increase in number during outbreaks of fruit tree red spider mite in Canadian peach orchards (Putman and Herne, 1966) and also to offer control of phytophagous mites in orchards and blackcurrant plantations in Russia (Lange et al., 1974; Livshits and Mitrofanov, 1981; Titov, 1987). Further research investigating the impact of A. baccarum upon economically important orchard invertebrate pests, such as apple rust mite and apple-grass aphid, proved that this species has the potential to form a valuable component of orchard IPM strategies (Cuthbertson et al., 2003 a,b; Cuthbertson and Murchie, 2004 b, 2005 d, 2006 c).

\section{Compatibility with chemical pesticides}

A study undertaken by Cuthbertson and Murchie (2003) indicated that A. baccarum can show various levels of compatibility with chemical fungicides commonly used within orchard ecosystems for the control of the fungal disease Venturia inaequalis, a major problem in Northern Irish apple orchards (Watters and Sturgeon, 1990). The study by Cuthbertson and Murchie (2003) also showed a link between leaf quality and apple rust mite numbers. Cuthbertson and Murchie (2006 d,e) also showed that orchard winter-washes and chemical pesticide applications aimed at controlling invertebrate pests which had detrimental effects on non-target species populations, such as A. baccarum. The beneficial mite was removed by the chemicals and as a result of this, and presumably depletion of other natural enemies, pest populations, such as apple rust mite increased within the orchards (Cuthbertson and Murchie, 2006d). In Canada, recent work by Laurin and Bostanian (2007 a,b) has shown that dry residues of the fungicides sulphur, captan and myclobutanil are harmless to $A$. baccarum as were the insecticides methoxyfenozide, acetamiprid, imidacloprid and spinosad. Anystis baccarum, therefore offers much potential to be incorporated into IPM strategies in apple orchards for invertebrate pest control (Cuthbertson and Muchie, 2009). Unnecessary chemical applications can also have negative impacts on other beneficial insects within orchard ecosystems, for example, honey bees which are vital for pollination of the crop (Fourez, 1995; Aizen et al., 2009; Cuthbertson and Brown, 2006; 2009).

\section{CONCLUSION}

In the development of orchard IPM programs, generalist predatory mites, such as A. baccarum, must also be fully researched to determine their impact upon pest species and included within any such IPM system implemented. Horticultural advisors and fruit growers alike must be fully aware of the biodiversity that occurs within an orchard ecosystem and ensure the correct identification of pest and beneficial species, thus eliminating unnecessary chemical applications. The inclusion of generalist predatory species within pest control programs has the potential to lead to a more sustainable apple production system, not only within Northern Ireland, but the British Isles as a whole (Cuthbertson and Murchie, 2006a; 2009).

\section{ACKNOWLEDGEMENTS}

Dr. Andrew G. S. Cuthbertson was funded by a Department of Agriculture and Rural Development (Northern Ireland) Studentship.

\section{REFERENCES}

Aizen, M. A.; Garibaldi, L. A.; Cunningham, S. A.; Klein, A. M., (2009). How much does agriculture depend on pollinators? Lessons from long-term trends in crop production. Ann. Bot., 103 (9), 1579-1588 (10 pages).

Anonymous, (1972). Apples. UK farming and the common market. A report by the economic development committee for agriculture. National Economic Development Office. London, UK.

Anonymous, (1992). A report on the market for processed apples. Local Enterprise Development Unit for Northern Ireland. Belfast, UK.

Baker, W. V., (1967). Some observations on predation in an anystid mite. Ent. Mon. Mag., 103 (1), 58-59 (2 pages).

Baker, R. T., (1983). Predation of leafroller larvae by spiders and mites. Weta, 6 (1), 22-23 (2 pages).

Banaee, M.; Mirvagefei, A. R.; Rafei, G. R.; Majazi Amiri, B., (2008). Effect of sub-lethal diazinon concentrations on blood plasma biochemistry. Int. J. Environ. Res., 2 (2), 189-198 (10 pages).

Carter, S.; Shaw, S. A., (1993). The UK apple industry: Production, markets and the role of diferentation. British Food J., 95 (10), 23-28 (6 pages).

Cook, M. C. F., (1998). An economic review of northern ireland apple production and marketing with special reference to bramley seedling. report for department of agriculture for Northern Ireland economics and statistics division.

Cranham, J. E.; Solomon, M. G., (1981). Mite management in commercial apple orchards. Report east malling research station for 1980. 171-172. 
Croft, B. A.; Kim, S. S.; Kim, D. I., (1995). Leaf residency and interleaf movement of four phytoseiid mites (Acari: Phytoseiidae) on apple. Environ. Entomol., 24 (5), 13441351 (8 pages).

Cross, J. V.; Berrie, A. M., (1994). Effects of repeated foliar sprays of insecticides or fungicides on organophosphateresistant strains of the orchard predatory mite Typhlodromus pyri on apple. Crop Prot., 13 (1), 39-44 (6 pages).

Cuthbertson, A. G. S., (2004). Unnecessary pesticide applications in Northern Ireland apple orchards due to misidentification of a beneficial mite species. Res. J. Chem. Environ., 8 (3), 77-78 (2 pages).

Cuthbertson, A. G. S., (2005). Rediscovery of a predatory mite in northern Irish apple orchards. Bio. News, 30 (1), 29 (1 page).

Cuthbertson, A. G. S.; Brown, M. A., (2006). Vital pollinators: Honey bees in apple orchards. Biologist, 53 (2), 78-81 (4 pages).

Cuthbertson, A. G. S.; Brown, M. A., (2009). Issues affecting British honey bee biodiversity and the need for conservation of this important ecological component. Int. J. Environ. Sci. Tech., 6 (4), 695-699 (5 pages).

Cuthbertson, A. G. S.; Murchie, A. K., (2003). The impact of fungicides to control apple scab (Venturia inaequalis) on the predatory mite Anystis baccarum and its prey Aculus schlechtendali (apple rust mite) in Northern Ireland Bramley orchards. Crop. Prot., 22 (9), 1125-1130 (6 pages).

Cuthbertson, A. G. S.; Murchie, A. K. (2004a). The presence of Anystis baccarum (L.) in Northern Ireland Bramley apple orchards. Ir. Nat. J., 27 (12), 465-467 (3 pages).

Cuthbertson, A. G. S.; Murchie, A. K., (2004b). The phenology, oviposition and feeding rate of Anystis baccarum, a predatory mite in Bramley apple orchards in Northern Ireland. Exp. Appl. Acarol., 34 (3-4), 367-373 (7 pages).

Cuthbertson, A. G. S.; Murchie, A. K., (2005a). European red spider mite - an environmental consequence of persistent chemical pesticide application. Int. J. Environ. Sci. Tech., 2 (3), 287-290 (4 pages).

Cuthbertson, A. G. S.; Murchie, A. K., (2005b). Techniques for environmental monitoring of predatory fauna on branches of Bramley apple trees in Northern Ireland. Int. J. Environ. Sci. Tech., 2 (1), 1-6 (6 pages).

Cuthbertson, A. G. S.; Murchie, A. K., (2005c). Environmental monitoring of Archips podana (fruit tree tortrix moth) in Bramley apple orchards in Northern Ireland. Int. J. Environ. Sci. Tech., 2 (2), 101-104 (4 pages).

Cuthbertson, A. G. S.; Murchie, A. K., (2005d). Anystis baccarum - an apple orchard assassin. Biologist, 52 (6), 324-327 (4 pages).

Cuthbertson, A. G. S.; Murchie, A. K., (2006a). Integrated pest management in Bramley's Seedling apple orchards in Northern Ireland. Biology Studies, 28 (2), 103-107 (5 pages).

Cuthbertson, A. G. S.; Murchie, A. K., (2006b). Environmental monitoring of economically important invertebrate pests in Bramley apple orchards in Northern Ireland. Int. J. Environ. Sci. Tech., 3 (1), 1-7 (7 pages).

Cuthbertson, A. G. S.; Murchie, A. K., (2006c). The role of Aculus schlechtendali (apple rust mite) in orchard pest management strategies in Northern Ireland. J. Entomol., 3 (4), 267-270 (4 pages).
Cuthbertson, A. G. S.; Murchie, A. K., (2006d). Environmental impact of an orchard winter wash and early season pesticide applications on both a beneficial and a pest mite species in Bramley apple orchards. Int. J. Environ. Sci. Tech., 3 (4), 333-339 (7 pages).

Cuthbertson, A. G. S.; Murchie, A. K., (2006e). A preliminary study into the direct effect of chemical pesticides on the predatory mite Anystis baccarum. Int. J. Physic. Sci., 18 (2), 177-180 (4 pages).

Cuthbertson, A. G. S.; Murchie, A. K., (2007a). A review of the predatory mite Anystis baccarum and its role in apple orchard pest management schemes in Northern Ireland. J. Entomol., 4 (4), 275-278 (4 pages).

Cuthbertson, A. G. S.; Murchie, A. K., (2007b). The necessity of correct species identification to avoid unnecessary pesticide application. J. Environ. Res. Develop., 1 (3), 269271 (3 pages).

Cuthbertson, A. G. S.; Murchie, A. K., (2007c). The life history of Rhopalosiphum insertum (apple-grass aphid) in Bramley's Seedling apple orchards. J. Entomol., 4 (2), 160162 (3 pages).

Cuthbertson, A. G. S.; Murchie, A. K., (2009). Anystis baccarum - a potential biocontrol agent in UK apple orchards. Proceedings of the $3^{\text {rd. }}$ International Symposium on Biological Control of Arthropods, Christchurch, New Zealand, 8-13 ${ }^{\text {th. }}$ February 2009. 366-373.

Cuthbertson, A. G. S.; Fleming, C. C.; Murchie, A. K., (2003a). Detection of Rhopalosiphum insertum (apple-grass aphid) predation by the predatory mite Anystis baccarum using molecular gut analysis. Agri. For. Entomol., 5 (3), 219-225 (7 pages).

Cuthbertson, A. G. S.; Bell, A. C.; Murchie, A. K., (2003b). Impact of the predatory mite Anystis baccarum (Prostigmata: Anystidae) on apple rust mite Aculus schlechtendali (Prostigmata: Eriophyidae) populations in Northern Ireland Bramley orchards. Ann. Appl. Biol., 142 (1), 107-114 (8 pages).

Defra, (2001). Basic horticultural statistics for the United Kingdom. Department for Environment Food and Rural Affairs, DEFRA Publications, Admail 6000, London, UK.

Defra, (2007). England and Wales National Statistics Department for Environment Food and Rural Affairs, Orchard Fruit Survey.

Dicke, M.; Sabelis, M. W.; van den Berg, H., (1989). Does prey preference change as a result of prey species being presented together? Analysis of prey selection by the predatory mite Typhlodromus pyri (Acarina: Phytoseiidae). Oecologia, 81 (2), 302-309 (8 pages).

Easterbrook, M. A., (1984). Effects of pesticides on the apple rust mite Aculus schlechtendali (Nal.) (Eriophyidae). J. Hort. Sci., 59 (1), 51-55 (5 pages).

Easterbrook, M. A.; Solomon, M. A.; Cranham, J. E.; Souter, E. F., (1985). Trials of an integrated pest management programme based on selective pesticides in English apple orchards. Crop Prot., 4 (2), 215-230 (16 pages).

El Banhawy, E. M.; Carter, N.; Wynne, I. R., (1993). Preliminary observations on the population development of anystid and free-living mesostigmatic mites in a cereal field in southern England. Exp. Appl. Acarol., $\mathbf{D}$ 549 (9 pages).

Fourez, A., (1995). Impact of pollination by bees (Apis 
Mellifera Linne) on the production of apples (cv Jonagold). Belg. J. Zool., 125 (1), 135-141 (7 pages).

Gerson, U.; Smiley, R. L., (1990). Acarine Biocontrol Agents: An illustrated key and manual. Chapman and Hall. London, UK.

Goulet, H. (2003). Biodiversity of ground beetles (Coleoptera: Carabidae) in Canadian agricultural soils. Can. J. Soil Sci., 83 (3), 259-264 (6 pages).

Horowitz, A. R.; Gorman, K.; Ross, G.; Denholm, I., (2003). Inheritance of pyriproxyfen resistance in the whitefly, Bemisia tabaci (Q biotype). Arch. Insect Biochem., 54 (4) 177-186 (10 pages).

Joy, V. C.; Pramanik, R.; Sarkar, K., (2005). Biomonitoring insecticide pollution using non-target soil microarthropods. J. Environ. Biol., 26 (3), 571-577 (8 pages).

Krantz, G. W., (1978). A manual of Acarology (2nd. Ed.), Oregon State University Book Stores, Inc.

Lange, A. B.; Drozdovskii, E. M.; Bushkovskaya, L. M., (1974). Anystid mites - effective predators of small phytophagous pests. Zashchita Rastenii, 1 (1), 26-28 (3 pages).

Laurin, M. C.; Bostanian, N. J., (2007a). Laboratory studies to elucidate the residual toxicity of eight insecticides to Anystis baccarum (Acari: Anystidae). J. Econ. Entomol., 100 (4), 1210-1214 (5 pages).

Laurin, M. C.; Bostanian, N. J., (2007b). Short-term contact toxicity of seven fungicides on Anystis baccarum. Phytoparasitica, 35 (4), 380-385 (6 pages).

Linnaeus, C., (1758). Systema Naturae. (10 ${ }^{\text {th. }}$ Ed.), L. Salvii, Holmiae.

Livshits, I. Z.; Mitrofanov, V. I., (1981). Beneficial insects and mites in fruit orchards. Zashchita Rastenii, 6 (1), 49-52 (4 pages).
MacQuillan, M. J., (1966). The mite fauna of a neglected northern Ireland apple orchard. Ent. Mon. Mag., 102 (2), 153-155 (3 pages).

Meyer, M. K. P.; Ueckermann, E. A., (1987). A taxonomic study of some Anystidae (Acari: Prostigmata). Republic of South Africa Department of Agriculture and Water Supply, Entomology Memoir No. 68.

Michaud, J. P., (2002). Non-target impacts of acaricides on ladybirds in citrus: A laboratory study. Fla. Entomol., 85 (1), 191-196 (6 pages)

Oudemans, A. C., (1937). Namensänderung. Archiv für Naturgeschichte (N.F), 6.

Putman, W. L.; Herne, D. H. C., (1966). The role of predators and other biotic agents in regulating the population density of phytophagous mites in Ontario peach orchards. Can. Entomol., 98 (3), 808-820 (13 pages).

Santos, M. A., (1976a). Evaluation of Zetzellia mali as predator R Panonychus ulmi and Aculus schlechtendali. Environ. Entomol., 5四), 187-191 (5 pages).

Santos, M. A., (1976b). Prey selectivity and switching response of Zetzellia mali. Ecology, $\square$ UाD), 390-394 (5 pages).

Stoll, O., (1886). Biologia Centrali - Americana. Zoologia. Arachnida Acaridae. Taylor and Francis. London, UK

Titov, D. A., (1987). Beneficial insects in the orchard. Zashchita Rastenii, 2 (1), 56-57 (2 pages).

Trägardh, I., (1905). Acariden aus Ägypten und dem Sudan. In: Results of the Swedish zoological expedition to Egypt and the white Nile. Part II.

Watters, B. S.; Sturgeon, S. R., (1990). An evaluation of fungicides against apple scab (Venturia inaequalis) in Bramley's Seedling. Tests of Agrochem. Cult. No.11 (Ann. Appl. Biol. Suppl.), 116 (1), 38-39 (2 pages).

AUTHOR (S) BIOSKETCHES

Cuthbertson, A. G. S., Ph.D., Senior Applied Entomologist, The Food and Environment Research Agency in York, England, UK. Email: andrew.cuthbertson@fera.gsi.gov.uk

Murchie, A. K., Ph.D., Senior Scientific Officer, The Agri-Food and Biosciences Institute in Belfast, Northern Ireland, UK. E-mail: archie.murchie@afbini.gov.uk

How to cite this article: (Harvard style)

Cuthbertson, A. G. S.; Murchie, A. K., (2010). Ecological benefits of Anystis baccarum in an orchard ecosystem and the need for its conservation. Int. J. Environ. Sci. Tech., 7 (4), 807-813. 